\title{
Ninety-Third Annual Report of The American Phytopathological Society
}

\section{REPORT OF THE TREASURER}

The Financial Advisory Committee (FAC) and APS headquarters' staff members met on 11 August 2000 in New Orleans and 20 October 2000, 23 February 2001, and 3 May 2001 in St. Paul, MN during FY00-01 to review financial matters related to the operation of the Society. The notes from these meetings have been approved by FAC and notes of all meetings are on file at APS headquarters.

After allocations for maintenance reserves, operating reserves, and capital improvement expenses, FY00-01 was concluded with a deficit of $\$ 106,507$, which represents $2.7 \%$ of income. The 10 income and expense categories for the Society are detailed in Table 1. Our total income $(\$ 3,952,594)$ was derived from eight sources as indicated in Figure 1, and our total operating expenses $(\$ 4,059,101)$ incurred during FY00-01 were partitioned as indicated in Figure 2. The deficit resulted from increased expenses such as the initiation of new activities that include the Plant Health Progress electronic journal, the Education Center, obtaining professional assistance to support our public policy activities, and lower than anticipated revenue from product sales. The in- come and expenses of the Society for the most recent $10 \mathrm{FYs}$ are presented in Table 2. The total assets of the Society as of 30 June 2001 , including restricted funds, were $\$ 4,581,588$ and current liabilities totaled $\$ 3,443,522$, producing a membership equity of $\$ 1,138,065$ that includes the FY00-01 deficit of \$106,507. During FY00-01, several initiatives continued under development to enhance member services and improve outreach, and many aspects of the Strategic Plan for the Society were implemented as

TABLE 2. Comparison of The American Phytopathological Society fiscal years 1992 to 2001 before reserve allocation

\begin{tabular}{lccc}
\hline Fiscal year & Income & Expenses & Surplus (deficit) \\
\hline FY01 & $\$ 3,952,594$ & $\$ 4,059,101$ & $(\$ 106,507)$ \\
FY00 & $\$ 3,649,863$ & $\$ 3,724,910$ & $(\$ 75,047)$ \\
FY99 & $\$ 3,662,093$ & $\$ 3,692,259$ & $(\$ 30,166)$ \\
FY98 & $\$ 3,589,253$ & $\$ 3,431,727$ & $\$ 157,526$ \\
FY97 & $\$ 3,418,515$ & $\$ 3,216,088$ & $\$ 202,427$ \\
FY96 & $\$ 3,198,990$ & $\$ 2,974,105$ & $\$ 224,885$ \\
FY95 & $\$ 3,152,468$ & $\$ 2,907,285$ & $\$ 245,183$ \\
FY94 & $\$ 3,062,160$ & $\$ 2,902,793$ & $\$ 159,367$ \\
FY93 & $\$ 2,843,296$ & $\$ 2,574,006$ & $\$ 269,290$ \\
FY92 & $\$ 2,689,171$ & $\$ 2,565,571$ & $\$ 123,600$ \\
\hline
\end{tabular}

TABLE 1. Audited summary of income and expenses as related to function of The American Phytopathological Society

\begin{tabular}{|c|c|c|c|c|c|c|c|c|c|}
\hline \multirow[b]{2}{*}{ Function } & \multicolumn{4}{|c|}{ Income } & \multicolumn{4}{|c|}{ Expenses } & \multirow[b]{2}{*}{ Profit (loss) } \\
\hline & Actual & $\%$ & Budget & $\%$ & Actual & $\%$ & Budget & $\%$ & \\
\hline Member services & $\$ 314,132$ & 7.95 & $\$ 322,500$ & 7.99 & $\$ 589,461$ & 14.52 & $\$ 617,097$ & 15.19 & $(\$ 275,329)$ \\
\hline Short course & $\$ 39,419$ & 1.00 & $\$ 67,625$ & 1.68 & $\$ 18,676$ & 0.46 & $\$ 81,854$ & 2.01 & $\$ 20,743$ \\
\hline Plant Disease & $\$ 642,694$ & 16.26 & $\$ 614,640$ & 15.22 & $\$ 372,432$ & 9.18 & $\$ 331,436$ & 8.16 & $\$ 270,262$ \\
\hline Phytopathology News & $\$ 6,043$ & 0.15 & $\$ 3,800$ & 0.10 & $\$ 64,615$ & 1.59 & $\$ 80,907$ & 1.99 & $(\$ 58,572)$ \\
\hline MPMI & $\$ 455,699$ & 11.53 & $\$ 377,950$ & 9.36 & $\$ 353,356$ & 8.71 & $\$ 262,943$ & 6.47 & $\$ 102,343$ \\
\hline $\mathrm{G} \& \mathrm{~A}^{\mathrm{a}}$ & $\$ 17,858$ & 0.45 & $\$ 41,700$ & 1.03 & $\$ 863,378$ & 21.27 & $\$ 819,452$ & 20.17 & $(\$ 845,520)$ \\
\hline Total & $\$ 3,952,594$ & 100.00 & $\$ 4,037,125$ & 100.00 & $\$ 4,059,101$ & 100.00 & $\$ 4,063,193$ & 100.00 & \\
\hline Operating surplus (loss) & & & & & & & & & $(\$ 106,507)$ \\
\hline
\end{tabular}

${ }^{\mathrm{a}} \mathrm{G} \& \mathrm{~A}$ is assigned to functions based on payroll dollars.

Income

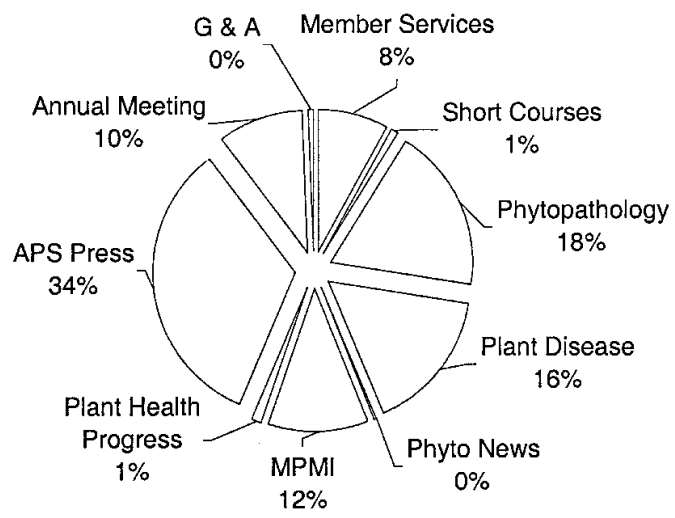

Expenses

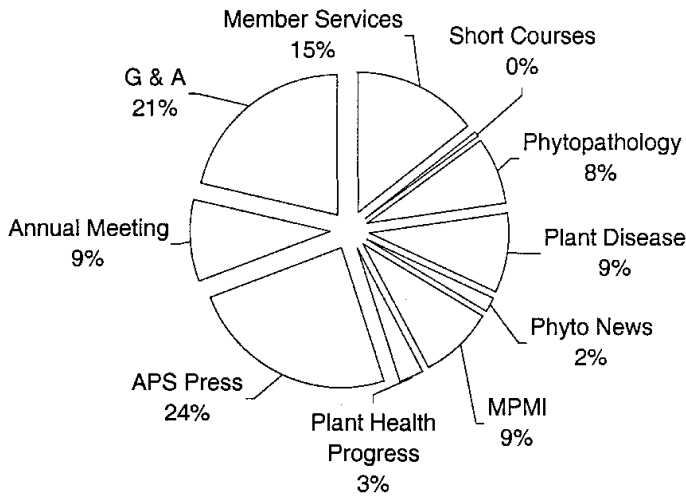

Fig. 2.
Fig. 1.

Publication no. P-2001-1112-010 
highlighted at the annual meeting in Salt Lake City. Of note are the enhanced content and interest in Plant Health Progress and the Education Center, and the increased use of reserves of the Society in supporting the APS Annual Meeting. Your recommendations related to the activities of APS should be expressed to

\section{REPORT OF THE AUDITOR}

The American Phytopathological Society has its accounts audited annually by a certified public accountant. In recent years, the accounting firm has been Lethert, Skwira, Schultz, \& Co., St. Paul, MN. Only the Balance Sheet and the Statement of Changes in Net Assets as of 30 June 2001, are being published in detail. Any member wishing a copy of the full audit may obtain one on request.

\begin{tabular}{|c|c|c|c|c|}
\hline & & 2000 & & 2001 \\
\hline \multicolumn{5}{|l|}{ Assets } \\
\hline Cash $\left(\right.$ note $\left.3^{\mathrm{a}}\right)$ & $\$$ & $1,149,859$ & $\$$ & $1,251,883$ \\
\hline Interest receivable & & 360 & & 306 \\
\hline Accounts receivable, net (notes 2 and 17) & & 157,342 & & 203,914 \\
\hline Unconditional promise to give & & - & & - \\
\hline Investments (note 4) & & $1,802,182$ & & $1,513,547$ \\
\hline Prepaid expenses (note 5) & & 350,119 & & 346,766 \\
\hline Inventory & & 657,288 & & 753,924 \\
\hline Prepaid pension (note 14) & & 58,104 & & 75,781 \\
\hline Property and equipment, net (note 6) & & 602,737 & & 546,379 \\
\hline Total assets & $\$$ & $4,777,991$ & $\$$ & $4,692,500$ \\
\hline \multicolumn{5}{|l|}{ Liabilities and net assets } \\
\hline Accounts payable (note 17 ) & $\$$ & 359,752 & $\$$ & 247,226 \\
\hline Accrued pension expense & & 30,160 & & 39,660 \\
\hline Agency funds payable & & 11,399 & & 10,931 \\
\hline Deferred revenues (note 7) & & $1,084,374$ & & $1,110,356$ \\
\hline Long-term debt (note 8) & & 3,090 & & 792 \\
\hline Total liabilities & & $1,488,775$ & & $1,408,965$ \\
\hline \multicolumn{5}{|l|}{ Net assets } \\
\hline Unrestricted (note 9) & & $2,580,233$ & & $2,469,806$ \\
\hline Temporarily restricted (note 10 ) & & 195,774 & & 199,159 \\
\hline Permanently restricted (note 11 ) & & 513,209 & & 614,570 \\
\hline Total net assets & & $3,289,216$ & & $3,283,535$ \\
\hline Total liabilities and net assets & $\$$ & $4,777,991$ & $\$$ & $4,692,500$ \\
\hline
\end{tabular}

a There are accompanying notes that are an integral part of this financial statement and are available upon request. members of the APS Council. With the increase of activity in many areas of APS, the income versus expenses for FY01-02 could be similar to that of FY00-01. The Treasurer can be contacted at sherwood@uga.edu. The audited financial statement for FY00-01 appears in this issue of Phytopathology.

The American Phytopathological Society statement of Changes in Net Assets Year ended 30 June 2001 (with comparative totals for 2000)

\begin{tabular}{|c|c|c|}
\hline & 2000 & 2001 \\
\hline \multicolumn{3}{|l|}{ Unrestricted net assets } \\
\hline \multicolumn{3}{|l|}{ Support and revenue } \\
\hline Federal financial assistance & 2,590 & 25,371 \\
\hline Contributions & 4,837 & 3,534 \\
\hline Membership dues & 270,880 & 285,741 \\
\hline Subscriptions & $1,228,372$ & $1,345,576$ \\
\hline Reprints and demand articles & 85,964 & 89,578 \\
\hline Abstracts & 17,940 & 20,795 \\
\hline Page charges & 160,772 & 156,655 \\
\hline Processing fees & 76,924 & 98,215 \\
\hline Back issues & 18,877 & 16,435 \\
\hline Color charges & 87,109 & 112,885 \\
\hline Advertising & 39,420 & 33,035 \\
\hline Books, slides, and CD-ROMs & $1,091,538$ & $1,289,099$ \\
\hline Annual meeting & 375,560 & 392,553 \\
\hline Short courses & 108,691 & 39,419 \\
\hline Management fee income & 2,999 & - \\
\hline Royalty income & 20,845 & 25,569 \\
\hline Investment income (note 4$)^{\mathrm{a}}$ & 72,477 & 95,959 \\
\hline Gain on sale of investments (note 4 ) & 75,089 & 34,607 \\
\hline Unrealized gain (loss) on investments (note 4) & 18,094 & $(148,107)$ \\
\hline Other & 23,697 & 31,567 \\
\hline Total revenue & $3,782,675$ & $3,948,483$ \\
\hline \multicolumn{3}{|l|}{ Net assets released from restrictions } \\
\hline Restrictions satisfied by payments & 56,405 & 61,053 \\
\hline \multicolumn{3}{|l|}{ Expenses } \\
\hline \multicolumn{3}{|l|}{ Program services } \\
\hline Member services & 493,246 & 617,399 \\
\hline Journals & $1,045,856$ & $1,210,343$ \\
\hline Books & 926,185 & $1,003,428$ \\
\hline Annual meeting & 367,991 & 403,058 \\
\hline Grants and awards & 19,200 & 25,786 \\
\hline Short courses & 122,389 & 18,677 \\
\hline Total program services & $2,974,867$ & $3,278,691$ \\
\hline \multicolumn{3}{|l|}{ Supporting services } \\
\hline Management and general & 828,567 & 841,653 \\
\hline Fund raising & 6,271 & (381) \\
\hline Total supporting services & 834,838 & 841,272 \\
\hline Total expenses & $3,809,705$ & $4,119,963$ \\
\hline Increase in unrestricted net assets & 29,375 & $(110,427)$ \\
\hline \multicolumn{3}{|l|}{ Temporarily restricted net assets } \\
\hline Support for books & 24,260 & 48,855 \\
\hline Support for annual meeting socials & 18,900 & 5,400 \\
\hline Support for conversion on changes & 4,631 & - \\
\hline Support for Virology Committe & - & 10,700 \\
\hline Support for student travel & 2,894 & 11,430 \\
\hline Investment income (note 4$)$ & 14,093 & 20,981 \\
\hline Gain (loss) on sale of investments (note 4 ) & 19,010 & 3,852 \\
\hline Unrealized gain (loss) on investments (note 4) & 5,773 & $(36,780)$ \\
\hline Restrictions satisfied by payments & $(56,405)$ & $(61,053)$ \\
\hline Increase in temporarily restricted net assets & 33,156 & 3,385 \\
\hline \multicolumn{3}{|l|}{ Permanently restricted net assets } \\
\hline Support for operations & 7,540 & 7,529 \\
\hline Support for student travel & 47,034 & 49,601 \\
\hline Support for student speaker & 131 & 10,075 \\
\hline Support for research & 2,939 & 1,340 \\
\hline Support for awards & 99,845 & 32,225 \\
\hline Unrealized loss on investments (note 4) & (394) & 591 \\
\hline Increase in permanently restricted net assets & 157,095 & 101,361 \\
\hline Decrease in net assets & 219,626 & $(5,681)$ \\
\hline Net assets, beginning of year & $3,069,590$ & $3,289,216$ \\
\hline Net assets, end of year & $\$ 3,289,216$ & $\$ 3,283,535$ \\
\hline
\end{tabular}

a There are accompanying notes that are an integral part of this financial statement and are available upon request. 